DEXA 装置の測定精度に関して経時的および日内変動 に関しては精度は高く問題がないように思われるが京都 第二日赤辻らの質問にもあったようにポジショニングの 変化によるバラツキに問題が有るようだ。骨粗箖症の患 者は長い時間同じポジションで検査を受けるのが辛くい かに短い時間で再現性の高い方法で検查ができるかが要 求される。また骨塩定量の測定は 1 回切りの測定ではな しに何年何十年と測定しなければいけない.このために $\mathrm{X}$ 線管のバラツキや測定器の精度も長期に渡る安定した 精度が望まれる。

また今回の演題にはなかったが DEXA 装置の機種間 による測定精度精難度も大きな問題であろう是非共長期 に渡る変動を調べてほしい所である。

[CT・MR】

座長 須賀大作（兵庫成人病センター）

18. 下肺野背側が腹側に比へ，高輝度に描出される症例 についての考察

奈良県立医科大学附属病院

○小田憲二・野儀明宏・水野吉将

土井 司・宇都文昭・宇山茂樹

〔目的〕胸部 CT Scanにおいて下肺野背側の輝度が 腹側に比べてわずかに高輝度に描出される症例の原因追 求.

〔方法〕比較する輝度の測定は, 右下肺野に限定し仰 臥位と腹臥位の ROI の CT 值をヒストグラフで表し正 常例, 腫瘍性疾患, 炎症性疾患それぞれについて比較検 討した．評価は仰臥位から腹臥位にする事によるCT 值 の変動をシフト率としシフト率に対する症例数より行う.

〔結果〕ほとんどの症例で体位変換により CT 值がシ フトし，肺内水分の重量効果が認められた。また，疾患 の違いによる明確な有意差は証明できなかった。しかし 正常例では，全例シフト率 $25 \%$ 以下に比べ炎症性疾患で は，著明にシフト率が上昇することがわかった。

\section{9. 眼薃・視神経撮像法の検討}

大津赤十字病院放射線部

○猪飼正夫・沢尾 誠・亀井宣明 小川 正・田濃孝司・畑山良吉

MRI 検査において, 眼窩・視神経の撮像は, 眼球の動 きによる artifact や aliasig artifact 出現のため, 像の劣 化が見られ診断の妨げとなる，その解決方法として，眼 球の抑制は，動きの artifact を除去するために必須であ り，また，RF シールド材を後頭部に挿入することによ り, aliasig artifactの影響を抑え，小さな有効視野での 撮像が可能となり, 分解能の向上につながる，同時に，
任意 matrix 法を用いることにより, 検査時間の短縮が でき，患者への負担の軽減を計ることができる。

\section{LOCALIZED 1H-MRS 臨床応用の技術的検討}

京都府立医科大学

○池尻 守・拵 信博・山口義和 成瀬昭二

局在 1H-MRSの測定にわれわれは現在 STEAM 法 を用いている.本法では TM, TE の条件を変えることに より,緩和時間や J-coupling に基ずく各種物質の多彩な 情報を得ることができる。しかし通常はながい TE $(270$ ms)での測定が主で STEAM 法が生かされていない.そ こでわれわれは, 傾斜磁場の調整, 渦電流の補正, TE の 短縮化 (135，100，50，34 ms）を行い測定した. その結 果 TEが短いほど信号強度は強くなり，ファントムでは TE $135 \mathrm{~ms}$ にて位相変調効果が認められた．正常脳では NAA, コリン, クレアチンが検出でき, 脳腫瘍では NAA の低下コリンの増化が認められた。 TEが短い場合に, 他 のアミノ酸のピーク(イノシトール, NAA-メチレン基) も認められ臨床的により有用なデータが得られる事が示 唆された。

\section{Presaturation Pulseを用いた選択的 MR-Angio-} graphy

京都府立医大放科

○拵 信博・池尻 守・山口義和

同脳外 成瀬昭二

MR アンギオグラフィは非侵襲的であり, Presaturation 法を用い容易に動静脈の分離や選択的血管の描出 が可能である. 2D 法は広範囲の血管の描出に適し, 特に 腹部血管全体を描出するのに優れている.3D 法は詳細な 分解能を有し頭頸部, 大動脈弓部および腎動脈などの描 出に優れている. $2 \mathrm{D}, 3 \mathrm{D}$ 法で得られた画像デー夕は 3 次 元再構成を行い, ステレオ視やシネ display を表示する ことで多彩な情報による診断が可能となった，血管性病 変などの症例に於ても血管造影や CT と同じ所見で良好 な結果が得られた。今後 MR アンギオグラフィがスクリ ーニングとして臨床応用できることが示された。

\section{座長集約}

兵庫県立成人病センター 須賀大作

近年の急速な技術進歩によって MRI はCT と同様に 画像診断上，重要な位置を占めるに至った。今回のCT, MRI の研究発表では, それぞれの特徴を生かした研究内 容となっている，CTでの研究発表は，MRIでは困難な 定量性を応用し, 肺水分量の疾患による変化を追求して いる. MRI の研究発表は, MRI, MRA, MRS と, MR 
の応用分野の全てを含む内容となった．特に非侵襲的に 行えるMRA では，頭部の主要血管はもとより，体幹部 の血管描出も盛んに研究, 開発されている現状であり, 今後もっとも注目される分野である。

演題18は, 下肺野背側が腹側に比べ, わずかに高濃度 に描出される現象に関する報告で，CT 值による定量性 を追求した発表である. 各群のピーク値の差から変動率 を求め, 5 \%単位のシフト率として，ノーマル群と疾患 群との比較を行っている，腫撚性，炎症性疾患で $20 \%$ 以 上のシフト率が多くなっているが, 有意差は認められな かったとしている。しかし今後のデータの収集と分析に より，有効な手段と成り得ることが期待できる.

演題19は, 眼窝, 視神経撮像法の検討で, MRI の機械 的特性を利用した画質の改善で，信号強度をできるだけ 損なわずに，簡便にノイズを低隇させている。

監問（滋賀県立成人病センター 安井）プレサチレ ーションの効果と比較してどうか.

答 本装置では，プレサチレーションがないので検討 していない.

罂問（同 安井）検出器を離す方法はどうか.

答 検出器を離すと, 眼球抢よび視神経などの, 分解 能が低下し画質への影響が問題となる，信号はできるだ け収集しかつアーチファクトだけ軽減させる主旨で行っ ている。

質問 （座長） $\mathrm{RF}$ シールド材を初めからセットして， チューニングを行うのか，その際 $\mathrm{RF}$ 条件のずれはない のか.

答 部分的に使用することと, ノイズ低減だけの最小 限のシールドとしたので影響はないと考えている。

演題20は, ローカライスド,プロトンMRS 臨床応用の 技術的検討で, STEAM 法では渦電流の影響から，エコ ータイムを短く設定できなかった従来の欠点を, 傾斜磁 場とパルス系列の調整により，TEを短く設定できるよ う改善し, 信号強度の増強を計っている. エコータイム $270 \mathrm{msec}$ を $34 \mathrm{msec}$ に短くした場合, 信号強度で 2 倍強 上昇する.また全体の信号収集から，各ポイント $2 \times 2 \mathrm{~cm}$ のマトリックスに再構成できる方法の開発を行っている. この方法を用いることで，コントロールを容易に確保す ることができ，治療効果の判定に有効と思われる。

演題21は，プレサチレーションパルスを用いた選択的 MR-アンギオグラフィの検討で, プレサチレーションを 使用することで，動静脈血管の分離，選択的血管の描出 ができることを, 症例を中心として報告した. また MRA の位置づけとして，スクリーニングとして使用できるこ
とを示唆している。

質問 (滋賀県立成人病センター 安井) 時間短縮に有 効な256×192のマトリックスの検討はされたか.

答 若干の時間短縮を行うょり，10分間検查を行った ほうが, 血管走行, 末梢の描出能が良い. しかし息止め 3D では，192，さらに160までマトリックスを落とすこと が可能である。

質問（同 安井）FISP3D と FLASH3Dではフリ ップアングルもさほど変わっていないが，どう違うのか.

答 画像の比較検討は行っていないが，FLASH では, スポイラーを用いていることから，位相の違いはあると 考える.

\section{【放射線治療】}

22. 治療用補助器具の製作

座長 岡田 孝 (京都大学)

大阪大学医学部附属病院中央放射線部

○桜井邦昭・菊池利邦・伊藤慎弥

川越康充・松本光弘・川原雅昭

森 嘉信

〔目的〕今回われわれは，簡単に安価に入手できる材 料や廃品などを利用して，どの施設でも製作可能な補助 具を製作した. 補助具としては，不整形照射野用鉛ブロ ック固定用外部投光器（ピンホールを用いた光源）と側 方向用固定用シャドウトレイ（圧着式）および不整形照 射用のパターン図, またグラフィ用のスケーラと高エネ ルギー用フィルムマーカおよび側面撮影用カセッテ保持 器を製作した.

〔結果〕（1) 患者セットアップの時間短縮

（2）不整形照射野における左右整合精度の向上.

（3）複雑なブロック配置の容易化など，日常の照射に 大変有用である。

(4) リニアックグラフィにスケール，マーカを入れる ことにより照射野の照合や修正などの作業が，容易に精 度よく行える。

23. X線位䉕決め透視像のテジタルビテオアタプターの 応用

大阪市立大学医学部付属病院中央放射線部 ○市田隆雄・椎崎信彦・木村俊彦 辻 政代・大村昌弘・白石順二 伊藤敬三・小野正夫・池田穂積

食道や肺，横隔膜を含む部位の放射線治療を行うとき， 位置決め時においてそれらの部位が呼吸などにより動く ため, 照射野内に十分含まれているかが問題になること がある. 今回，われわれは市販の安価なソニーデジタル 